\title{
The Millennials' Energy Efficiency Behaviour towards Eco-friendly Home
}

\author{
Maranatha Wijayaningtyas ${ }^{1, *}$, RES. Mangun Redjo ${ }^{2}$, Fourry Handoko $^{3}$, Kukuh Lukiyanto ${ }^{4}$, \\ Wilson Rangga A. A. J. ${ }^{5}$ \\ ${ }^{1}$ Department of Civil Engineering, National Institute of Technology (ITN) Malang, Malang, 65152, Indonesia \\ ${ }^{2}$ Housing and Settlement Areas Office, North Maluku, 97725, Indonesia \\ ${ }^{3}$ Department of Industrial Engineering, National Institute of Technology (ITN) Malang, Malang, 65152, Indonesia \\ ${ }^{4}$ Entrepreneurship Program, Bina Nusantara University, Malang Campus, 65145 Indonesia \\ ${ }^{5}$ Department of Real Estate, Faculty of Built Environment, Universiti Teknologi Malaysia, Johor Bahru, 81310, Malaysia
}

Received December 2, 2020; Revised February 7, 2021; Accepted March 12, 2021

\section{Cite This Paper in the following Citation Styles}

(a): [1] Maranatha Wijayaningtyas, RES. Mangun Redjo, Fourry Handoko, Kukuh Lukiyanto, Wilson Rangga A. A. J. , "The Millennials' Energy Efficiency Behaviour towards Eco-friendly Home," Civil Engineering and Architecture, Vol. 9 , No. 2, pp. 394-403, 2021. DOI: 10.13189/cea.2021.090212.

(b): Maranatha Wijayaningtyas, RES. Mangun Redjo, Fourry Handoko, Kukuh Lukiyanto, Wilson Rangga A. A. J. (2021). The Millennials' Energy Efficiency Behaviour towards Eco-friendly Home. Civil Engineering and Architecture, 9(2), 394-403. DOI: 10.13189/cea.2021.090212.

Copyright $\bigcirc 2021$ by authors, all rights reserved. Authors agree that this article remains permanently open access under the terms of the Creative Commons Attribution License 4.0 International License

\begin{abstract}
Having an environmentally friendly and energy-efficient house is a critical requirement today as this has a positive impact on residents and the surrounding environment, which supports the improvement of the three main pillars of the concept of sustainable development. However, many factors influence the energy-saving behaviour of households, especially the millennial generation. This study aims to identify and analyse the millennial generation's behaviour towards energy efficiency activities in environmentally friendly houses using the Theory of Planned Behaviour. The quantitative method was applied with a cross-sectional survey method and analysis with structural equation modelling. The respondents were 200 millennials in Malang and Surabaya with purposive random sampling. The analysis resulted that attitudes have a positive effect of 0.22 , subjective norms have a positive effect of 0.44 , and perceived behavioural control has a positive effect of 0.19 on the energy efficiency intention. The results also showed that perceived behavioural control and energy efficiency intention partially have a positive effect of 0.61 on energy efficiency behaviour. Based on the analysis and hypothesis testing results, it is concluded that subjective norm and attitudes positively and significantly affect the millennial generation's energy efficiency intention, besides perceived behavioural control. Thus, this study
\end{abstract}

will support the sustainable development stakeholders so that it will lead to understanding the millennials' behaviour and reasons for safe energy in eco-friendly homes concerning appropriate energy usage rules.

Keywords Eco-friendly, Behaviour, Energy Efficiency, Occupants, Millennial

\section{Introduction}

Increasing global population and economical consumption have penetrated society for almost a century. Therefore, natural resources are scarce and have an impact on reducing energy use [1,2]. In this context, individuals today express a higher level of awareness and concern about the environment than they did decades ago. Several areas of study present consumers' behaviour and role in today's economy, and much of this literature deals with the conceptualisation of green products and their presence in diverse markets $[3,4]$. Researchers in the social sciences have looked at attitudes and motivations towards environmentally friendly products, with much of the work addressing variables that predict environmentally-conscious human behaviour [5]. 
The attitude of environmentally aware consumers also impacts their behaviour to live in an environmentally friendly home. The house has a critical function for humans, apart from being a residence means; it reflects its owner. House defined as a building that functions as a habitable place to living, a means of fostering a family, reflecting the dignity of its residents, and a vital asset to its owner [6]. The high number of people who need a place to live is predicted to increase until 2030; Indonesia receives a demographic bonus, where the number of productive age population will be greater than the population of non-productive age [7].

Increased energy conservation is used for the control of home resources through energy saving, not only in ordinary housing, but also in green development and green buildings. In Indonesia, many houses and settlements have exceeded their capacity so that environmentally friendly residential development has begun to be offered to the community [8]. The trend for eco-friendly houses is new, as most Indonesian consumers have different perspectives for eco-friendly or green products $[9,10]$. Some have the same awareness and objective of saving the environment, but only buy the best products are influenced in part by culture around [11]. In addition, some consumers are going to buy something very carefully. However, they have realized that ecological concept houses are a trend in Indonesia and lifestyle changes must also take place [8]. Some of them follow sustainability and are driven to switch from conventional to ecological practices [12].

In the use of electric energy, the national energy consumption of the housing sector in Indonesia accounts for $30 \%$ and most of the use is in urban areas, based on data obtained from the Ministry of Energy and Mineral Resources of the Republic of Indonesia [13]. The behaviour of energy use and housing control depends on the individual occupants' awareness to not trigger excessive energy consumption. Therefore, it is necessary to have socialisation and action to raise awareness, understanding and motivation, fostering efficient energy use behaviour to preserve the environment [4]. Socialisation activities to raise awareness are related to the residents' social activities and the surrounding community. It can be faster in transferring knowledge and awareness of the importance of saving energy in the house $[1,14]$. However, the perceived perception regarding energy saving will differ from one occupant to another.

Additionally, individual behaviour and understanding of energy-saving are also influenced by the surrounding environment. In general, two categories influence this, contextual and psychological [15]. The psychological category is an internal factor of behaviour, while the contextual category is the energy use system, which may be different for each feature, the climate of the residential area, the physical and residential building attributes, and energy marketing [16]. It can be added that user satisfaction when determining to buy and occupy an environmentally friendly house is also influenced by energy efficiency $[17,18]$. Thus, the energy efficiently and effectively applied in the house depends on the occupants' behaviour, which will be discussed in this study.

The increasing population growth of the millennial generation will undoubtedly affect the amount of housing needed. This condition happens because the higher the population increase; the number of housing needs will also increase. A millennial generation is a population group born in 1978-2000 [4]. The increase in the number of the millennial population, in particular, can be seen from the rate of population growth that occurs in Malang City. Based on data in 2011, it is known that the population of Malang City in the productive age (25-40 years) reached 252,965 people. This number is known to have increased by $5.49 \%$ to 266,862 people in 2020 [19]. The increase in the population indicates an increase in the number of housing needs.

The millennial generation is known as the generation that likes to spend money, but with the many products available, they also tend to be more careful before buying a product [20]. Current technological developments easily influence the millennial generation to consume and behave based on their lifestyle [21]. Noh and Mosier [22] also explained that Generation $\mathrm{Y}$ is a group that can attract marketers because they have intelligence in technology. They are easy to obtain information about a product and are willing to take risks. They also follow energy-saving behaviour and tend to do so following an environmentally friendly lifestyle.

The preceding provides an understanding that a millennial generation is a group that can quickly obtain information about a product and tend to be more careful before behaving. Therefore, for housing developers who want to build eco-friendly housing and make the millennial generation consumers, they need to understand the millennial generation's behaviour, namely the factors that affect energy efficiency intention and behaviour when dwelling. This study examines the theory of planned consumer behaviour by analysing attitude, subjective norms and perceived behavioural control on millennial generation energy efficiency intentions and behaviour when dwelling in an eco-friendly home. This study's results are expected to help housing developers know more about the factors influencing millennial energy efficiency intentions and behaviour in an eco-friendly home, with the view to deciding on a strategy at minimising energy consumption in an eco-friendly home.

\section{Literature Review}

\subsection{Occupants Energy Efficiency Behaviour}

Low energy use and efficient consumption can simultaneously result in a lower total consumption value than initial use, and this activity is called energy efficiency [23,24]. Another opinion states that energy 
conservation has the same understanding as energy efficiency and energy conservation, which means that low energy production affects low energy consumption, describing how much energy is consumed [25,26]. Therefore, in discussing energy efficiency, these terms are interrelated and refer to the conclusion of energy consumption's importance towards efficient use. Some of the main concepts that must be considered towards energy-efficient buildings are indoor/outdoor planning concepts, natural ventilation, plants and water circulation management, windbreakers, sun shading and thermal materials-envelope [27].

User awareness is needed to support efforts to reduce energy consumption in residential buildings. The users and residents' behaviour can affect energy consumption, and this condition has been explored. Fabi et al. [27] evaluated how different patterns of behaviour for opening and closing windows affect indoor climate quality and energy consumption, and building control systems. According to Soares et al. [28], it is necessary to have a probabilistic approach to show more realistic occupants' behaviour towards energy savings.

\subsection{The Millennial Generation}

According to Kotler and Amstrong [29], the millennial generation is a population group born in 1978-2000. Current technological developments easily influence the millennial generation to consume and buy the desired product [30]. Noh and Mosier [22] opined that Generation $\mathrm{Y}$ is a group of consumers who have the potential to become an attraction for marketers because they have intelligence in technology, easy to obtain information about a product, and dare to take risks. Millennial generation consumers are known to like to spend money, but with many products available, they also tend to be more careful before buying a product [31].

\subsection{Attitudes and Energy Efficiency Intention}

Listyoningrum and Albari opined that attitude is a learned tendency to consistently react to product offerings in excellent or bad problems [32]. Referring to O'Callaghan et al.'s research results [33], it is known that attitudes have a positive effect on energy efficiency intention. Thus, attitudes are defined as the millennial generation's positive or negative feelings towards energy efficiency in the eco-friendly home by considering the advantages of energy-saving features. Therefore, resulting in the formulation of the hypothesis $\mathrm{H} 1$ :

H1: Attitudes have a positive and significant effect on millennial energy efficiency intention in an eco-friendly home.

\subsection{Subjective Norm and Energy Efficiency Intention}

Subjective norms are social pressure on someone to do or not take action [34,35]. It has been observed that subjective norms positively and significantly affect energy consumption intention [36]. In this study, an analysis of the influence of subjective norms on millennial energy efficiency intention will be carried out, with subjective norms as social influences from family and friends on the millennial generation towards energy efficiency intention in eco-friendly homes. Thus, the hypothesis $\mathrm{H} 2$, that:

$\mathrm{H} 2$ : Subjective norms positively and significantly affect millennial energy efficiency intention in an eco-friendly home.

\subsection{Perceived Behavioural Control and Energy Efficiency Intention}

Perceived behavioural control is one of the psychological factors that influence human behaviour. According to Wijayaningtyas et al. [37], the perceived behaviour control reflects the control of trust behaviour about access to resources and opportunities needed to perform a behaviour. Previous research results indicate that perceived behavioural control positively affects consumer purchase intentions [38]. In this study, perceived behavioural control is defined as the millennial generation's perceptions regarding energy efficiency benefit, environment quality and cost of energy efficiency features. Based on this, the hypothesis is obtained in this study; thus:

H3: Perceived behavioural control has a positive and significant effect on millennial energy efficiency intention in an eco-friendly home.

\subsection{Perceived Behavioural Control and Energy Efficiency Behaviour}

According to Ajzen [39], perceived behavioural control describes a person's perception of a person's ease or ability to behave. It thus implies that behaviour arises because of the perceived behaviour control when individuals have the understanding and confidence to take action [40]. Previous research has it that perceived behaviour control significantly affects purchasing decisions [41]. In this study, an analysis of the effect of perceived behavioural control on energy efficiency for the millennial generation was conducted to prove this. Thus, the hypothesis used in this study is:

H4: Perceived behaviour control has a positive and significant effect on the millennial energy efficiency behaviour in an eco-friendly home.

\subsection{Energy Efficiency Intention and Behaviour}

An energy efficiency intention is a form of desire to be wise and efficient when consuming energy. Previous research found that energy efficiency intention has a positive and significant effect on energy-saving behaviour $[42,43,44]$; the higher the intention, the higher the saving 
energy behaviour [45,46]. This has informed analysis of the millennial generation's energy efficiency intention on their behaviour in an eco-friendly home and the formulation of the hypothesis $\mathrm{H} 5$ :

H5: Energy efficiency intention has a positive and significant effect on the millennial energy efficiency behaviour in an eco-friendly home.

Based on the explanation of the theory and research hypothesis, a research concept is obtained that can be described in a frame of mind, as shown in Figure 1.

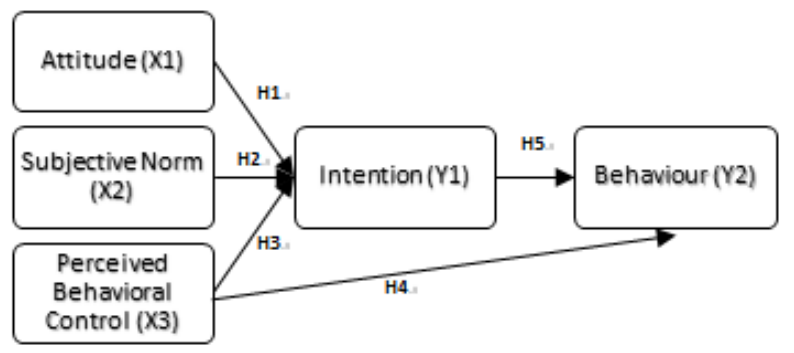

Figure 1. Research Conceptual Framework (Adopted from Ajzen [38])

\section{Materials and Methods}

This research adopted the quantitative paradigm and conducted the survey method by distributing a structured self-administered questionnaire based on the reviewed literature to the target sample and measured the theoretical prediction based on the hypotheses with statistical analysis, using descriptive and inferential analysis.

\subsection{Data Collection}

The data used in this study are primary since it uses a survey method; primary data are obtained from distributing instruments in questionnaires to potential respondents. Meanwhile, the literature review was conducted to determine the behavioural variables, theory suitability, and compare the research findings with previous research results. Furthermore, the questionnaire was structured based on indicators and variables in behavioural theory studied in previous studies to test and confirm its application to the millennial generation behaviour towards energy efficiency in eco-friendly homes. Self-distributing questionnaires with cross-sectional were carried out as primary data collection methods. The first reason for using this method is to provide a higher response rate than questionnaires distributed by mail, telephone and electronically. Second, respondents can directly ask the researcher about things that are still unclear after reading the questionnaire. Third, this technique is very flexible for obtaining data.

\subsection{Population and Sample}

The research population is defined as the number of the millennial population in Surabaya and Malang City, which has an age range of 25 years to 40 years. Based on the data obtained, both cities' populations aged 25 years to 40 are 693,658 people [16]. Thus, by using the calculation of the Slovin formula with a confidence level of $5 \%$, it is found that the minimum number of respondents needed is 200 people. The sampling method used for this research is non-probability with purposive sampling. The selected respondents are expected to answer the problem's objective related to energy-saving behaviour, namely that the millennial generation individual has occupied a house in the eco-friendly home category (in a residential area with a Green concept) in Malang and Surabaya.

\subsection{Research Variables}

Attitudes (X1) are positive or negative feelings of the millennial generation towards energy efficiency in an eco-friendly home by considering the advantages of energy-saving features. The indicators used in measuring attitude variables are as follows:

1. Using electricity saving features (X1.1).

2. Easy to use energy-saving features (X1.2).

3. Using natural ventilation (X1.3).

4. Using low voltage household appliance (X2.4).

5. I feel the advantages of using energy-saving features (X1.5).

6. I feel comfortable using energy-saving features (X1.6).

7. Using water consumption saving features (X1.7).

Subjective norms (X2) are social influences from family and friends on the millennial generation toward energy efficiency intention in eco-friendly homes. Based on this definition, indicators used to explain subjective norms are as follows:

1. Influence from parents (X2.1).

2. Influence of siblings (X2.2).

3. Influence of life partner (X2.3).

4. Influence from colleagues (X2.4).

5. Influence of friends (X2.5).

6. Influence from neighbours (X2.6).

For Perceived Behavioural Control (X3) as perceptions of the millennial generation regarding energy efficiency benefit, environment quality and cost of energy efficiency features, the indicators used are:

1. Perceived the lower electricity bill (X3.1).

2. Perceived the lower maintenance costs (X3.2).

3. Perceived the quality of a comfortable house (X3.3).

4. Perceived the lower water account (X3.4).

5. Perceived the ability to buy energy saving features (X3.5).

An energy efficiency intention is a form of desire to be wise and efficient when consuming the energy in an eco-friendly home. The indicators used are:

1. I want to save energy (Y1.1). 
2. I need to save energy at home (Y1.2).

3. I intend to purchase energy-saving features (Y1.3).

The energy efficiency behaviour is the response of the millennial generation to saving energy in an eco-friendly home. The indicators used to explain the behaviour are:

1. Satisfied with the decision to be energy efficient at home (Y2.1).

2. The right decision to be energy efficient at home (Y2.2).

3. I will maintain saving energy in my home (Y2.3).

\subsection{Research Instruments}

This study uses a Likert scale as a measurement scale for variables that indicate the level of agreement on a statement. On a Likert scale, the agreement level consists of five answer choices consisting of:

1. Strongly agree gets a score of 5

2. Agree gets a score of 4

3. Quite agree gets a score of 3

4. Disagree gets a score of 2

5. Strongly disagree gets a score of 1

The research instrument test consisted of testing the validity and reliability testing of Cronbach's Alpha. In testing the validity, the instrument is declared valid if it has a coefficient value of $r$-count $>$ r-table, whereas, in reliability testing, the instrument is declared reliable if the Cronbach's Alpha coefficient value has a value of $>0.6$.

\subsection{Data Analysis}

This study's data analysis consisted of descriptive and inferential analysis. The descriptive analysis performs mean and percentage values from each indicator. Next, inferential analysis using the PLS (partial least square) method and hypothesis testing was applied for the WarpPLS program. In the analysis of the PLS method, the stages of analysis include:

1. Make PLS construct based on the research hypothesis.

2. Outer model measurement is to measure the validity and reliability of the instrument in the PLS model. In this study, the validity measurement is measured based on the variable correlation value with the AVE square coefficient with good conditions if the instrument correlation value on the original variable is greater than the correlation value for other variables. While the measurement of reliability is measured based on the value of the composite reliability coefficient with the provision that it is reliable if it has a coefficient value of more than 0.7 .

3. Inner model evaluation is used to measure the PLS construct's ability to predict the effect's research variables. The ability to build can be seen based on the Tenenhaus GoF (Goodness of Fit) coefficient value obtained from the analysis with model level criteria, namely the weak model (GoF value $>=0.1)$, medium model $(\mathrm{GoF}$ value $>=0.25$, and robust model ( GoF value $>=0.36$ )

4. The analysis results of the WarpPLS program are indicated by the coefficient values of $\beta, R 2$, and $P$. Coefficient $B$ shows the value of the effect of the independent variable $(\mathrm{X})$ on the dependent variable (Y). The coefficient R2 shows the ability of variable $\mathrm{X}$ to explain variable $\mathrm{Y}$. The $\mathrm{P}$ coefficient is used to prove the research hypothesis by comparing the $\mathrm{P}$-value with a significance of 0.05 .

Hypothesis testing is done by comparing the P-value obtained from the WarpPLS program's analysis with a significance value of 0.05 . The hypothesis's provisions are accepted with a $\mathrm{P}$-value $<0,05$, and the hypothesis is rejected if the $\mathrm{P}$-value $>0,05$.

\section{Results and Discussion}

\subsection{Validity and Reliability Test}

Before the instrument test was carried out, the researcher first conducted a pilot study that took questionnaire data with a purposive sampling technique from 200 respondents based on the research respondents' criteria. Based on these data, an instrument test was then performed, consisting of testing the validity and reliability of Cronbach's Alpha to determine the research instrument's validity and reliability. The results of the validity and reliability test are shown in Table 1 and Table 2. 
Table 1. Test Validity Results

\begin{tabular}{|c|c|c|c|c|}
\hline Variables & Indicators & R-count & R-table & Result \\
\hline \multirow{7}{*}{ Attitude (X1) } & $\mathrm{X} 1.1$ & 0,481 & 0,361 & Valid \\
\hline & $\mathrm{X} 1.2$ & 0,310 & 0,361 & Not Valid \\
\hline & $\mathrm{X} 1.3$ & 0,419 & 0,361 & Valid \\
\hline & $\mathrm{X} 1.4$ & 0,711 & 0,361 & Valid \\
\hline & $\mathrm{X} 1.5$ & 0,669 & 0,361 & Valid \\
\hline & $\mathrm{X} 1.6$ & 0,713 & 0,361 & Valid \\
\hline & $\mathrm{X} 1.7$ & 0,647 & 0,361 & Valid \\
\hline \multirow{6}{*}{ Subjective Norms (X2) } & $\mathrm{X} 2.1$ & 0,497 & 0,361 & Valid \\
\hline & $\mathrm{X} 2.2$ & 0,570 & 0,361 & Valid \\
\hline & $\mathrm{X} 2.3$ & 0,695 & 0,361 & Valid \\
\hline & $\mathrm{X} 2.4$ & 0,809 & 0,361 & Valid \\
\hline & $\mathrm{X} 2.5$ & 0,718 & 0,361 & Valid \\
\hline & $\mathrm{X} 2.6$ & 0,495 & 0,361 & Valid \\
\hline \multirow{5}{*}{$\begin{array}{c}\text { Perceived Behavioural } \\
\text { Control (X3) }\end{array}$} & $\mathrm{X} 4.1$ & 0,761 & 0,361 & Valid \\
\hline & $\mathrm{X} 4.2$ & 0,769 & 0,361 & Valid \\
\hline & $\mathrm{X} 4.3$ & 0,874 & 0,361 & Valid \\
\hline & $\mathrm{X} 4.4$ & 0,841 & 0,361 & Valid \\
\hline & $\mathrm{X} 4.5$ & 0,829 & 0,361 & Valid \\
\hline \multirow{3}{*}{ Intention (Y1) } & Y1.1 & 0,880 & 0,361 & Valid \\
\hline & Y1.2 & 0,786 & 0,361 & Valid \\
\hline & Y1.3 & 0,902 & 0,361 & Valid \\
\hline \multirow{3}{*}{ Behaviour (Y2) } & Y2.1 & 0,868 & 0,361 & Valid \\
\hline & $\mathrm{Y} 2.2$ & 0,909 & 0,361 & Valid \\
\hline & Y 2.3 & 0,825 & 0,361 & Valid \\
\hline
\end{tabular}

(Source: Result Analysis)

Table 2. Test Reliability Results

\begin{tabular}{|c|c|c|c|}
\hline Variables & Number of Indicators & (ri) Alpha Cronbach's & Result \\
\hline Attitude (X1) & 7 & 0,633 & Reliable \\
\hline Subjective Norms (X2) & 6 & 0,663 & Reliable \\
\hline Perceived Behavioural Control (X3) & 5 & 0,869 & Reliable \\
\hline Intention (Y1) & 3 & 0,814 & Reliable \\
\hline Behaviour (Y2) & 3 & 0,828 & \\
\hline
\end{tabular}

(Source: Result Analysis)

In Table 1, it is known that the validity test results show that in addition to $\mathrm{X} 1.2$, all instruments are declared valid because they have a calculated $r$-value greater than $r$ table 0.361 . The R-table value is obtained based on the moment product value of $r$ table $(\mathrm{N}=30)$. Based on the provisions, if there is an invalid instrument, it needs to be replaced or deleted. So the step taken by the researcher was to remove the X1.2 instrument from the research instrument so that only valid ones were left. All valid instruments were then used to collect data from the questionnaire administered to the 200 respondents.

Table 2 shows that all instruments have a Cronbach alpha coefficient value greater than 0.6 . These results explain that all research instruments are reliable and appropriate for collecting data from the structured questionnaire administered to the respondents.

\subsection{Descriptive Analysis}

Descriptive statistics in research describe and make conclusions (from deduction or inferences) regarding the data obtained based on the minimum, maximum, average (mean) and standard deviation values. Based on the responses from 200 respondents, the results of the calculation of the mean, standard deviation, minimum value of 56 and maximum value of each of the calculation 
variables are shown in Table 3.

Table 3. Descriptive Analysis Results

\begin{tabular}{|c|c|c|c|c|}
\hline No & Indicators & Total & Mean & Percentage \\
\hline 1 & $\mathrm{X} 1.1$ & 112 & 3.73 & $75 \%$ \\
\hline 2 & $\mathrm{X} 1.3$ & 119 & 3.97 & $55 \%$ \\
\hline 3 & $\mathrm{X} 1.4$ & 110 & 3.67 & $83 \%$ \\
\hline 4 & $\mathrm{X} 1.5$ & 122 & 4.07 & $78 \%$ \\
\hline 5 & $\mathrm{X} 1.6$ & 115 & 3.83 & $78 \%$ \\
\hline 6 & $\mathrm{X} 1.7$ & 112 & 3.73 & $78 \%$ \\
\hline 7 & $\mathrm{X} 2.1$ & 124 & 4.13 & $73 \%$ \\
\hline 8 & $\mathrm{X} 2.2$ & 114 & 3.80 & $70 \%$ \\
\hline 9 & $\mathrm{X} 2.3$ & 115 & 3.83 & $75 \%$ \\
\hline 10 & $\mathrm{X} 2.4$ & 111 & 4.70 & $80 \%$ \\
\hline 11 & $\mathrm{X} 2.5$ & 112 & 4.73 & $83 \%$ \\
\hline 12 & $\mathrm{X} 2.6$ & 110 & 4,40 & $80 \%$ \\
\hline 13 & $\mathrm{X} 3.1$ & 122 & 4.07 & $83 \%$ \\
\hline 14 & $\mathrm{X} 3.2$ & 127 & 4.37 & $78 \%$ \\
\hline 15 & $\mathrm{X} 3.3$ & 130 & 4.33 & $86 \%$ \\
\hline 16 & $\mathrm{X} 3.4$ & 133 & 4.43 & $84 \%$ \\
\hline 17 & $\mathrm{X} 3.5$ & 121 & 4.03 & $85 \%$ \\
\hline 18 & Y1.1 & 123 & 4.00 & $70 \%$ \\
\hline 19 & Y1.2 & 119 & 3.97 & $77 \%$ \\
\hline 20 & Y1.3 & 121 & 4.00 & $86 \%$ \\
\hline 21 & Y2.1 & 118 & 4,26 & $88 \%$ \\
\hline 22 & $\mathrm{Y} 2.2$ & 125 & 4.00 & $82 \%$ \\
\hline 23 & Y2.3 & 122 & 4,23 & $85 \%$ \\
\hline
\end{tabular}

(Source: Result Analysis)

\subsection{PLS Method Analysis}

The results of the outer model's measurement areas obtained are shown in Table 3 and Table 4. Table 3 shows that the research instrument on each variable is valid in a discriminant manner. This was based on the correlation value of the square root $\mathrm{AVE}$ of each variable which is greater than the correlation coefficient value for other variables. Therefore, it suggests that the research instrument is valid for use in the PLS model. Table 4 reveals that the reliability measurement results indicate that all variables have a composite reliability coefficient value greater than 0.7 ; it explains that the research variables are reliable and are suitable for the research model.

Table 4. Measurement Results of Outer Model

\begin{tabular}{|c|c|c|c|c|c|}
\hline & $\mathrm{X} 1$ & $\mathrm{X} 2$ & $\mathrm{X} 3$ & $\mathrm{Y} 1$ & $\mathrm{Y} 2$ \\
\hline $\mathrm{X} 1$ & 0.648 & 0.076 & 0.231 & 0.203 & 0.357 \\
\hline $\mathrm{X} 2$ & 0.076 & 0.698 & -0.050 & -0.114 & -0.043 \\
\hline $\mathrm{X} 3$ & 0.231 & -0.050 & 0.701 & 0.427 & 0.626 \\
\hline $\mathrm{Y} 1$ & 0.203 & -0.114 & 0.427 & 0.724 & 0.297 \\
\hline $\mathrm{Y} 2$ & 0.357 & -0.043 & 0.626 & 0.297 & 0.885 \\
\hline
\end{tabular}

(Source: SEM-PLS Result Analysis)

Table 5. Measurement Results of Composite Reliability

\begin{tabular}{|c|c|c|}
\hline Variable & CR & Result \\
\hline X1 & 0.803 & Reliable \\
\hline X2 & 0.824 & Reliable \\
\hline X3 & 0.825 & Reliable \\
\hline Y1 & 0.764 & Reliable \\
\hline Y2 & 0.915 & Reliable \\
\hline
\end{tabular}

(Source: SEM-PLS Result Analysis)

The inner model evaluation results show that the study's model is robust because it has a GoF coefficient value = $0.524>0.36$. Thus, it can be said that the research model is suitable for predicting the millennial generation behaviour in energy efficiency towards eco-friendly homes in Surabaya and Malang.

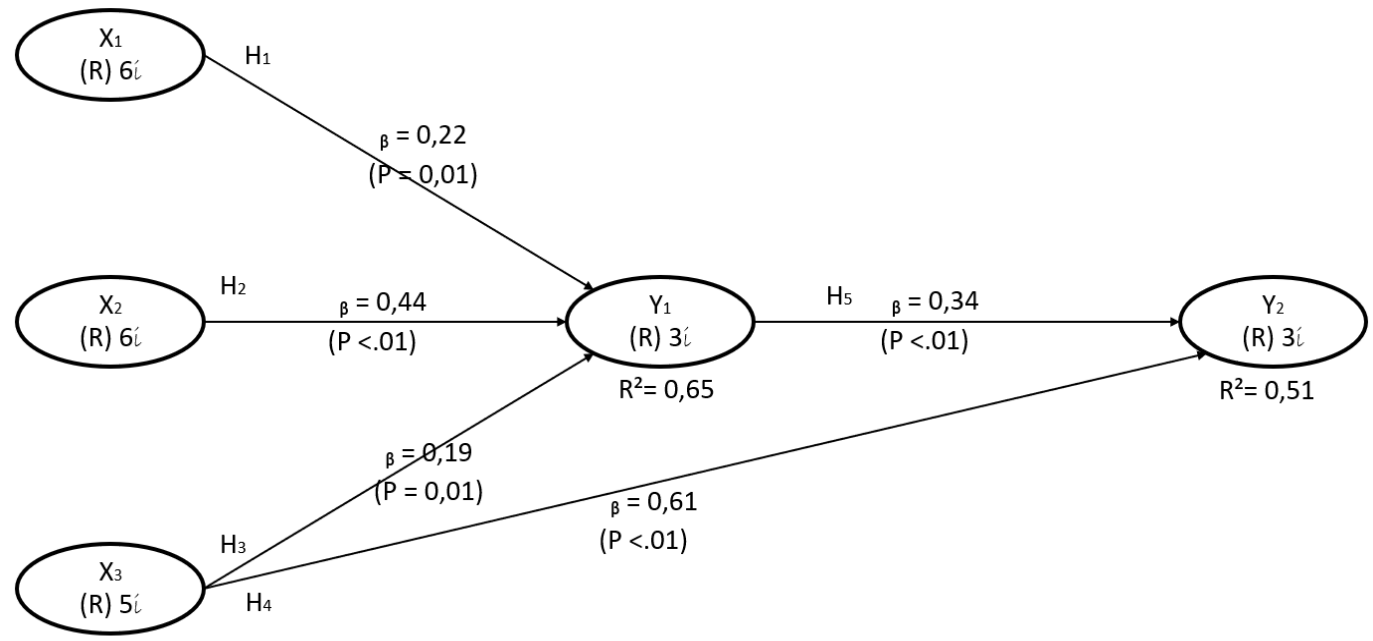

Figure 2. Structured Model (Source: SEM-PLS Result Analysis) 
Figure 2 implies that the $\beta$ value describes the magnitude of the influence that $\mathrm{X} 1, \mathrm{X} 2$, and $\mathrm{X} 3$ affect $\mathrm{Y} 1$, similar to $\mathrm{X} 3$ and $\mathrm{Y} 1$ on $\mathrm{Y} 2$. The values of $\beta(\mathrm{X} 1, \mathrm{Y} 1)=$ $0.22, \beta(\mathrm{X} 2, \mathrm{Y} 1)=0.44, \beta(\mathrm{X} 3, \mathrm{Y} 1)=0.19$, explaining that the increase in energy efficiency intention (Y1) is influenced by an increase in attitude (X1) of 0.22 , subjective norms $(\mathrm{X} 2)$ of 0.44 , and perceived behavioural control (X3) of 0.19. It suggests that $\beta(\mathrm{X} 3, \mathrm{Y} 2)=0.61$, and $\beta(\mathrm{Y} 1, \mathrm{Y} 2)=0.34$, this value explains that any increase in energy efficiency behaviour (Y2) is influenced by an increase in perceived behavioural control (X3) of 0.61 , and intention (Y1) of 0.34 .

The value of $\mathrm{R} 2=0.65$ at $\mathrm{Y} 1$ explains that attitude $(\mathrm{X} 1)$, subjective norms (X2), and perceived behavioural control (X3) together are able to have an effect of $65 \%$ on energy efficiency intention (Y1), and other variables outside the research model influence the rest. Therefore, it implies that the value of $\mathrm{R} 2=0.51$ at $\mathrm{Y} 2$, meaning that perceived behavioural control (X3) and intention (Y1) together can only affect $51 \%$ of energy efficiency behaviour (Y2) and other variables outside the research model influence the rest.

Hypothesis testing is based on the $\mathrm{P}$ coefficient value obtained from the PLS construct analysis. Figure 2 reveals that the value of $\mathrm{P}(\mathrm{X} 1, \mathrm{Y} 1)=0.01, \mathrm{P}(\mathrm{X} 2, \mathrm{Y} 1) \leq 0.01, \mathrm{P}$ $(\mathrm{X} 3, \mathrm{Y} 1)=0.01$. Following the hypothesis testing provisions, the hypothesis with a significance value of $\mathrm{P}$ $<0.05$ is the accepted hypothesis. These results, therefore, indicate that the accepted hypotheses are hypothesis $\mathrm{H} 1$, $\mathrm{H} 2$, and $\mathrm{H} 3$, which confirms that partial attitudes (X1), subjective norms (X2), and perceived behavioural control (X3) have a significant effect on the energy efficiency intention of the millennial generation towards eco-friendly home.

Figure 3 shows the $\mathrm{P}$-value in testing the behaviour hypothesis, namely $\mathrm{P}(\mathrm{X} 3, \mathrm{Y} 2) \leq 0.01$, and $\mathrm{P}(\mathrm{Y} 1, \mathrm{Y} 2) \leq$ 0.01 . The P-value provisions (X3, Y2) show that the hypothesis $\mathrm{H} 5$ is accepted because it has a $\mathrm{P}$-value $<0.05$, which confirms that perceived behavioural control (X3) has a positive and significant effect on millennial generation energy efficiency in an eco-friendly home. The $\mathrm{P}$-value (Y1, Y2) suggests that the H5 hypothesis is also accepted because it has a $\mathrm{P}$ value $>0.05$ significance. Therefore, it implies that intention (Y1) has a positive and significant effect on the millennial generation energy efficiency behaviour (Y2).

The results of the accepted hypothesis testing support the results of previous studies that the attitude has a positive effect on intention, subjective norms have a significant effect on intention, perceived behavioural control has a positive effect on intention, and perceived behavioural control has a significant and positive effect on behaviour $[15,35,37,40,42]$. At the same time, there are no rejected hypotheses. Previous research outcomes have shown that subjective norms have a positive and significant effect on purchase intention. Therefore, this study corroborated that subjective norms have the highest value, positive and significant influence on millennial generation's energy efficiency intention concerning the eco-friendly home.

\section{Conclusions}

This study proves the theory of planned behaviour's predictive power that the three determinants of positive intention influence millennial generation behaviour to save energy. This study also supports previous research that shows that millennial generation individuals with environment-friendly knowledge and awareness significantly and positively influence the intention to buy a green residential building. In line with that, this study's results indicate that attitude, subjective norm and perceived behavioural control simultaneously positively and significantly influence intention, ultimately affecting behaviour. However, the subjective norm is a dominant influencing factor, meaning that the higher and more positive support from family and friends to the millennial generation to save energy, the more it affects them to act on energy efficiency in eco-friendly homes.

This research is supposed to provide practical recommendations for stakeholders on sustainable development goals (SDG) in Indonesia, namely the government, industry, especially property developers with environmentally friendly concepts, media, education, and society. This study indicates that the millennial generation, as the most significant potential consumers, has energy efficiency intentions and behaviours starting from their homes. It was found that the influence of family and friends in the environment where they lived and worked was the main factor in their actions to save energy. Thus, the government's recommendations are expected to have policies and rules related to energy efficiency, such as promoting energy-saving activities and giving appreciation for those who apply energy efficiency, both in the home and work environment. Furthermore, the implication of this research for property sector developers is that they can prioritise building and marketing environmentally-friendly concept houses or buildings targeting millennial generation consumers to support Indonesia's sustainable development.

This research limitation is related to selecting respondents' object and location in that it only examined the millennial generation in Malang and Surabaya. It only uses the quantitative method with closed-ended questions based on the variables in planned behaviour theory. So, it is hoped that in the following research, the respondents will be the millennial generation and live in other big cities in Indonesia, or by comparing the energy efficiency behaviour of several generations. It is also advisable to use qualitative research methods or mixed methods to understand the natural phenomena related to Indonesian 
society's energy efficiency perceptions and behaviour.

\section{Acknowledgments}

We are very grateful to housing developers with a "green" name for their appropriate and constructive suggestions to support this study's data.

\section{REFERENCES}

[1] S. Hidayat, F. Handoko, M. E. Tjahjadi, and P. Vitasari. The Triple Helix and Technology Capability and Competitiveness of SMEs in Developing Economy, International Journal of Civil Engineering and Technology, vol. 9, no. 13, pp. 366-378, 2018, Accessed: Oct. 17, 2020. [Online]. Available: http://www.iaeme.com/ijciet/issues.asp ?JType $=$ IJCIET \&VType $=9 \&$ IType $=13$

http://www.iaeme.com/IJCIET/issues.asp?JType=IJCIET\& VType=9\&IType=13http://www.iaeme.com/IJCIET/index. asp367.

[2] F. Handoko, M. Wijayaningtyas, I. H. A. Kusuma, S. Hidayat, A. Ismail, and Z. Abdullah. The occupational health and safety effect on road construction worker performance, Civil Engineering and Architecture, vol. 8, no. 5, pp. 750-759, 2020, doi: 10.13189/cea.2020.080502.

[3] X. Tong and J. Su. Exploring young consumers' trust and purchase intention of organic cotton apparel, Journal of Consumer Marketing, vol. 35, no. 5, pp. 522-532, 2018, doi: 10.1108/JCM-04-2017-2176.

[4] M. Wijayaningtyas and T. H. Nainggolan. The millennial generation purchase intention toward green residential building, International Journal of Scientific and Technology Research, vol. 9, no. 2, pp. 2054-2059, 2020.

[5] A. M. F. Paço and M. L. B. Raposo. Green consumer market segmentation: empirical findings from Portugal, International Journal of Consumer Study, vol. 34, no. 1996, pp. 429-436, 2010, doi: 10.1111/j.1470-6431.2010.00869.x.

[6] Pemerintah Indonesia (Indonesia Government). Undang-Undang Republik Indonesia Nomor 1 Tahun 2011 Tentang Perumahan dan Kawasan Permukiman (Law of The Republic on Indonesia Number 1 Year 2011 Concerning Housing and Residential Areas), 2011.

[7] medcom.id. Pembangunan Rumah tak Sepadan dengan Jumlah Masyarakat (House construction is not commensurate with the number of people), www.medcom.id, 2020 .

[8] R. Sugandhi and R. Hakim. Prinsip Dasar Kebijakan Pembangunan Berkelanjutan Berwawasan Lingkungan (Basic Principles of Environmentally Sustainable Development Policy). Jakarta: Bina Aksara, 2007.

[9] M. Wijayaningtyas. Pengaruh Mediasi Sikap Generasi Y Terhadap Niat Beli Rumah Ramah Lingkungan (The Effect of Generation Y's Attitude Mediation towards the Eco-Friendly Home Purchase Intention), Jurnal Manajemen Kearifan Lokal Indonesia, vol. 1, no. 2, p. 71, 2017, doi: 10.26805/jmkli.v1i2.7.

[10] M Wijayaningtyas, Ibrahim Sipan, Wai, C. W. Effect of environmental knowledge and concern toward attitude of green home buyers' intention in Surabaya, in Knowledge, Service, Tourism \& Hospitality: Proceedings of the Annual International Conference on Management and Technology in Knowledge, Service, Tourism \& Hospitality 2015 (SERVE 2015), Bandung, Indonesia, 1-2 August 2015, 2016, p. 167.

[11] N. S. A. Adiwoso, Prasetyoadi, and S. Perdana. Towards Indonesia Sustainable Future through Sustainable Building and Construction, 2013. [Online]. Available: http://www.mgbc.org.my/Resources/Day 2/GBC Indonesia Presentations/Country Paper - GBC Indonesia Presentation Paper.pdf.

[12] L. T. M. Astuti, P. Tjiptoherijanto, H. Haeruman, and R. Koestoer. Model of Sustainable Wellbeing on Decent House Study Case of Bekasi City, West Java, Indonesia, Procedia Environmental Science, vol. 28, no. April 2016, pp. 370-379, 2015, doi: http://dx.doi.org/10.1016/j.proenv.2015.07.046.

[13] S. J. D. E. Nasional. Outlook Energi Indonesia 2016 (Indonesia Energy Outlook 2016), 2016. [Online]. Available: https://www.esdm.go.id/assets/media/content/outlook_ener gi_indonesia_2016_opt.pdf.

[14] F. Handoko, E. Nursanti, D. Harmanto, and Sutriono. The role of tacit and codified knowledge within technology transfer program on technology adaptation, ARPN Journal of Engineering and Applied Sciences, vol. 11, no. 8, pp. 5275-5282, 2016.

[15] P. Wang, Q. Liu, and Y. Qi. Factors influencing sustainable consumption behaviors: A survey of the rural residents in China, Journal of Cleaner Production, vol. 63, pp. 152-165, 2014, doi: 10.1016/j.jclepro.2013.05.007.

[16] T. Chikweche, J. Stanton, and R. Fletcher. Family purchase decision making at the bottom of the pyramid, Journal of Consumer Marketing, vol. 29, no. 3, pp. 202-213, 2012, doi: $10.1108 / 07363761211221738$.

[17] M. Wijayaningtyas, F. Ahmadi, and T. H. Nainggolan. Millennials' perception toward the Residence with Green Building Concept, International Journal of Scientific Engineering and Science, vol. 2, no. 10, pp. 40-44, 2018.

[18] M. Wijayaningtyas, S. Hidayat, T. Halomoan Nainggolan, F. Handoko, K. Lukiyanto, and A. Ismail. Energy Efficiency of Eco-Friendly Home: Users' Perception, in E3S Web of Conferences, 2020, vol. 188, doi: 10.1051/e3sconf/2020188 00019 .

[19] Badan Pusat Statistik Kota Malang, Jumlah Penduduk di Kota Malang Menurut Kelompok Umur dan Jenis Kelamin, 2011-2020 (Total Population in Malang City by Age Group and Gender, 2011-2020), malangkota.bps.go.id, 2020.

[20] Alvara. Behaviors and Preferences of Indonesian Millennial Consumers on E-Commerce Applications in 2019, Alvara Strategies Research, vol. July 9, pp. 1-57, 2019, [Online]. Available: https://alvara-strategic.com/wp-content/uploads/2019/07/P RESS-CON-ENGLISH-E-COMMERCE-REPORT.pdf.

[21] T. Angela and N. Effendi. Faktor-Faktor Brand Loyalty Smartphone pada Generasi Y (Generation Y Smartphone Brand Loyalty Factors), Experientia, vol. 3, pp. 79-91, 2015. 
[22] M. Noh and J. Mosier. Effects of young consumers' self-concept on gedonic/utilitarian attitudes towards what is 'cool, International Journal of Fashion Design Technology and Education, vol. 7, no. 3, pp. 163-169, 2014.

[23] A. Steinemann, P. Wargocki, and B. Rismanchi. Ten questions concerning green buildings and indoor air quality, Building Environmental, vol. 112, no. November 2016, pp. 351-358, 2017, doi: 10.1016/j.buildenv.2016.11.010.

[24] M. N. Uddin, A. M. Selvam, J. Shahoonda, and R. Prasanth. Optimisation of green building for low-income people at pondicherry, Civil Engineering and Architecture, vol. 6, no. 6, pp. 283-292, 2018, doi: 10.13189/cea.2018.060602.

[25] C. Wilson and H. Dowlatabadi. Models of Decision Making and Residential Energy Use, Annual Review of Environmental Resources, vol. 32, no. 1, pp. 169-203, 2007, doi: 10.1146/annurev.energy.32.053006.141137.

[26] A. Shandilya, M. Hauer, and W. Streicher. Optimisation of thermal behavior and energy efficiency of a residential house using energy retrofitting in different climates, Civil Engineering and Architecture, vol. 8, no. 3, pp. 335-349, 2020, doi: 10.13189/cea.2020.080318.

[27] V. Fabi, G. Spigliantini, and S. P. Corgnati. Insights on Smart Home Concept and Occupants' Interaction with Building Controls, Energy Procedia, vol. 111, no. August, pp. 759-769, 2017, doi: 10.1016/j.egypro.2017.03.238.

[28] N. Soares and L. D. Pereira. Energy efficiency of higher education buildings: a case study, International Journal of Sustainable in Higher Education, 2016, [Online]. Available: https://eg.uc.pt/bitstream/10316/44799/1/2015 Soares_et_a 1_2015_Eenrgy Efficiency of higher education building.pd.

[29] P. Kotler and A. Gary, Principles of Marketing. 2008.

[30] G. Ordun. Millennial (Gen Y) Consumer Behavior Their Shopping Preferences and Perceptual Maps Associated With Brand Loyalty, Canadian Social Sciences, vol. 11, no. 4, pp. 1-16, 2015, doi: 10.3968/pdf_294.

[31] S. Ulla Puustelli. Buying Behaviour of Millennials Changing Traditional Marketing Practices, no. April, 2kukuh016.

[32] A. Listyoningrum and A. Albari. Analisis Minat Beli Konsumen Muslim Terhadap Produk Yang Tidak Diperpanjang Sertifikat Halalnya (Analysis of Muslim Consumers' Purchase Intention of Products for which the Halal Certificate is Not Extended), Journal Ekonomi Keuangan Islam, vol. 2, no. 1, pp. 40-51, 2012.

[33] B. O'Callaghan, H. J. Green, R. A. Hyde, D. Wadley, and A. Upadhyay. Exploring the influence of housing design and occupant environmental attitudes on energy and water usage, Architecture Sciences Review, vol. 55, no. 3, pp. 176-185, 2012, doi: 10.1080/00038628.2012.693813.

[34] S. Kiriakidis. Theory of Planned Behaviour: the Intention-Behaviour Relationship and the Perceived Behavioural Control (PBC) Relationship with Intention and Behaviour, International Journal of Strategic Innovation Marketing, vol. 03, pp. 40-51, 2015, doi: 10.15556/IJSIM.02.03.004.
[35] Lukiyanto, K and Wijayaningtyas, M. Gotong royong as social capital to overcome micro and small enterprises' capital difficulties, Heliyon, vol. 6, no. 9, e04879, 2020, doi: 10.1016/j.heliyon.2020.e04879.

[36] H. da S. Tamashiro and J. da Silveira. The relationship between ecological knowledge, ecological concern, ecological affection, subjective norms and the green purchase behavior in Brazil, African Journal of Business Management, vol. 7, no. 34, pp. 3297-3314, 2013, doi: 10.5897/AJBM12.1270.

[37] M. Wijayaningtyas, F. Handoko, and S. Hidayat. The millennials' perceived behavioural control on an eco-friendly house purchase intention, Journal of Physics: Conferences Series, vol. 1375, no. 1, pp. 1-7, 2019, doi: 10.1088/1742-6596/1375/1/012060.

[38] M. Ng and M. Law. Encouraging Green Purchase Behaviours of Hong Kong Consumers, Asian Journal of Business Research, vol. 5, no. 2, pp. 1-17, 2015, doi: 10.14707/ajbr.150013.

[39] I. Ajzen. The theory of planned behaviour: Reactions and reflections, Psychology Health, vol. 26, no. 9, pp. 1113 1127, 2011, doi: 10.1080/08870446.2011.613995.

[40] Y. Shumaila, G. R. Foxall, and J. G. Pallister. Explaining internet banking behavior: Theory of reasoned action, theory of planned behavior, or technology acceptance model?, Journal of Applied Social Psychology, vol. 40, no. 5, pp. 1172-1202, 2010, doi: 10.1111/j.1559-1816.2010.00615.x.

[41] M. T. Nawawi. Analisis Faktor-Faktor Yang Mempengaruhi Keputusan Konsumen Dalam Pembelian Produk Makanan Dan Minuman Halal Di Jakarta (Analysis of Factors Affecting Consumer Decisions in Purchasing Halal Food and Beverage Products in Jakarta), Jurnal Muara Ilmu Ekonomi dan Bisnis, vol. 2, no. 1, p. 72, 2018, doi: 10.24912/jmieb.v2i1.1662.

[42] Handoko, F., Nursanti, E., Gatot, Tjahjadi, M.E., Hutabarat, J., Mulyadi, L., and Kustamar. Green Industrial System in Indonesia, MATEC Web Conferences, 164 (2018) 01010, 2018, DOI: https://doi.org/10.1051/matecconf/2018164010 10

[43] Handoko, F., Vitasari, P., Hidayat, S., Tjahjadi ME. Technology transfer program for SMEs in Indonesia, Journal of Physics: Conference Series, 1375(1), 012053, 2018.

[44] Laksmana, D.I. and Wijayaningtyas, M. Integration fasicility management: human resources, International Journal of Scientific and Technology Research, vol. 8, no. 12, pp. 701-705, 2019.

[45] D. Pertiwi, W. Suprapto, and E. Pratama. Perceived Usage of E-Wallet among the Y Generation in Surabaya based on Technology Acceptance Model, Jurnal Teknologi Indonesia, vol. 22, no. 1, pp. 17-24, May 2020, doi: 10.9744/jti.22.1.17-24.

[46] X. Liu, C. Wang, T. Shishime, and T. Fujitsuka. Sustainable consumption: Green purchasing behaviours of urban residents in China, Sustainable Development, vol. 20, no. 4, pp. 293-308, 2012, doi: 10.1002/sd.484. 